\title{
Challenges and Possibilities Facing European Higher Education
}

\author{
Suzy Harris
}

University of Roehampton. Department of Education

s.harris@roehampton.ac.uk

Received: 01-05-2009

Accepted: 09-06-2010

\begin{abstract}
This article considers the extent to which economic considerations are driving European and national higher education policy. This privileging of the economic imperative can be seen quite clearly in the internationalisation of higher education agenda. The article draws attention to the impoverished language of educational and political debate, where questions about the purpose and value of higher education are never asked; there is an emphasis on method and procedure rather than on substantive questions of value. A central challenge is to find a more subtle language that that moves beyond the impoverished language of performativity and allows us to ask profound questions about the purpose and value of higher education.
\end{abstract}

Key words: internationalisation; Bologna; university; European Union; language.

\section{Resumen. Retos y posibilidades que afronta la enseñanza superior europea}

El artículo analiza hasta qué punto las consideraciones económicas orientan la política de educación superior europea y nacional. La priorización de criterios económicos se ve claramente en el caso de la internacionalización de la agenda de la educación superior. Este artículo centra su atención en el empobrecimiento del lenguaje de debate educativo y político, debate que ya no plantea cuestiones sobre la finalidad y el valor de la educación superior, sino que se observa que se pone mayor énfasis en el método y en los procedimientos que en los aspectos sustantivos y de valor. Se argumenta que el principal desafío que se propone es encontrar un idioma más sutil que permita formular preguntas más profundas acerca de la finalidad y el valor de la educación superior, capaz de ir más allá del lenguaje empobrecido de la performativity.

Palabras clave: internacionalización; Bolonia; universidad; Unión Europea; lenguaje. 
The demands and challenges of the global economy are significant factors in the growing importance attached to higher education, and to the internationalisation of higher education in both national and European policy (Altbach and Peterson, 1999; Luijten-Lub, 2007; Scott, 1998, 2000). Higher education has become an important marketable good and, as a consequence, has a higher political profile than in previous decades. The argument presented in this article is not derived from any sense of nostalgia for a golden past, when everything in academia was good, for there has never been such a time. Despite the expansion and "massification" of higher education, the university remains a site of exclusion, elitism and power. Nor is this article critical of the need for greater cooperation and understanding between European countries. The central concern relates to the language of education and political debate, which is impoverished and over-privileges economic concerns that prevents proper attention being paid to more fundamental concerns regarding the purpose of higher education. This is not to suggest that education does not, or should not have, an economic value: it is merely argued that there are other values that are equally important. It should be noted that the argument presented in this article is based on an analysis of higher education policy and practice in the UK, where the neoliberal project has been more vigorously pursued than in mainland Europe. The first part of the paper focuses primarily on the UK context while the second part considers the European policy context. Discussion is focused on universities rather than institutions of higher education more generally. ${ }^{1}$

\section{$-2-$}

There has been a change in the way we think about knowledge and the value we attach to knowledge, or to use the distinction made by Bernstein (2000), the intrinsic value of knowledge is not acknowledged as much as its extrinsic value. Today, socially relevant and applied knowledge is more important in what is commonly referred to as the "knowledge economy". Education is regarded as a form of knowledge capital, and as such is central to national governments' economic policies directed towards competition in the global market place (Peters and Hume, 2003). Knowledge produced for exchange value now appears to be more important than use value. The status of knowledge has been displaced from its central position and is no longer appreciated in its entirety; knowledge has been reduced to information. Jean François Lyotard observed the way in which excellence, performance and competitiveness have become central concepts in university teaching and research:

"the status of knowledge is altered as societies enter what is known as the post-industrial age and cultures enter what is known as the postmodern age ... The nature of knowledge cannot survive unchanged within this context of

1. The arguments here have been elaborated in Harris (2007). 
general transformation ... The old principle that the acquisition of knowledge is indissociable from the training (Bildung) of minds, or even of individuals, is becoming obsolete and will become ever more so." (Lyotard, 1984: 3-4, italics in original)

The education system is based on a measurable input-output model of education and requires standardisation. This can be seen most clearly in the UK, where what is most important is not the content of the teaching or research, but the fact that it is taught or researched "excellently". Research, for example, is measured in terms of publications and citation indices. To publish is not enough; an academic must publish in what are regarded as the "top" and most prestigious journals that are "international" or of "international significance" (Bridges, 2006; Harris, 2007, 2008). Such compliance to international standards of excellence privileges journals written in English. ${ }^{2}$

The criterion of excellence in academic work is no longer based primarily on intellectual grounds but on what is considered relevant, what offers best value. In other words, efficiency and effectiveness are the criteria on which judgments about education are based. What is most important in teaching is the achievement of "quality", defined as clear and unambiguous aims and objectives, learning outcomes and a transparent assessment system. Intellectual rigour as the criterion for professional expertise has been replaced by the new criteria of relevance, efficiency, effectiveness, and excellence (Ranson, 2003). Consequently, although universities have more autonomy over their budgets, they are exposed to far greater external scrutiny through assessment and accountability regimes that use a discourse of targets, audits and outcomes. This discourse may be persuasive but it is seriously flawed. We can see this with the case of accountability: a rich understanding of accountability implies being accountable for our words and actions; being held to account for our words and how we behave towards each other.$$
-3-
$$

One of the features of the contemporary university is the existence of a wider range of programmes designed to respond to the growing diversity of the student population associated with the massification of higher education. Students are able to pick and mix courses in a way they could not do before. The curriculum is highly compartmentalised, fragmented and specialised, broken down into bite-size learning. Particularly in the UK, the student population is also much broader and more international in composition (Watson, 2007). One result of the growing demand to make courses more student-centred - for

2. The influence of the market has also led to the privileging of certain forms of research. In Australia, for example, Simon Marginson $(1995,2000)$ has noted that the research that is most rewarded is that which connects to research markets and is linked to institutional strategy. Other kinds of research that are not connected to policy-related areas tend to be marginalised. 
example, through the use of on-line technology and more transparent assessment systems - is that less attention is given to matters of curriculum content, which is reduced to a concern about the most efficient form of "delivery". There exists an obsession with method, where emphasis is primarily placed on procedure rather than substantive questions of value. In a highly competitive market, students and parents have greater expectations and universities are increasingly concerned to ensure high levels of satisfaction because they cannot afford to lose students or their reputation.

In the contemporary university, autonomy and personalised learning have become central, and the idea of systematic intellectual enquiry that was once central to the university has disappeared. For example, learning is now regarded as an autonomous process, which implies a denial of any kind of relationship or connection to, and understanding of, others. Social relationships between teachers and students are constructed as calculated exchanges (Masschelein and Simons, 2002). In other words, the teacher-student relationship has been reduced to a technical and functional phenomenon.

\section{$-4-$}

The boundaries between the university and business have become blurred as successive governments have encouraged universities to engage in commerce and collaborate with business. Unsurprisingly, this is transforming traditional academic discourse within the university, particularly in terms of governance and management but also in relation to the curriculum. The language of "performativity" and marketing is pervasive, the most recent example of which is the emergence of enterprise as a core part of university business. How enterprise is defined varies across institutions. Universities which are concerned primarily with widening participation tend to use the term to demonstrate their readiness to produce employable graduates, whereas research-intensive universities tend to use the term to describe their collaboration with big business, (Harris, 2011). The relationship between the university and business is of course important: for instance, there is a practical and technical need for employees to possess good language skills to carry out their jobs. Naturally, employers expect university graduates to have acquired these skills before they leave university. The danger is in privileging the acquisition of a portfolio of skills and competences over an engagement with ideas and different ways of thinking informed by a particular disciplinary tradition. Historically, the latter has been a central purpose of the university.

Pierre Bourdieu (1988) makes an important distinction between academic power and intellectual power, and notes that intellectually renowned thinkers such as Althusser and Foucault all held marginal positions in the university system. Today, there is increasing pressure on academics to pursue what Brooks (2001) refers to as the "correct professional identity". It is increasingly important that academic activity contributes to the institution's overall strategy of maintaining and improving its market position, which places more pressure on 
individuals to pursue and construct academic identities in line with a corporate identity. Corporate image and identity becomes increasingly important as universities sell themselves and their "brand name", which intensifies institutional competition as they compete to maintain their market position in a constantly changing global knowledge economy (Cunningham et al, 2000; Readings, 1996; Slaughter and Rhodes, 2004). In a devastating observation of what he describes as the "corporatisation of the university", Bill Readings (1996: 175) writes "[thought] is non-productive labor, and hence does not show up on the balance sheets except as waste."

How academics respond to this challenge will be experienced differently depending on gender, age, and institutional context. In Christine Skelton's (2004) study of various generations of female academics in the UK, the younger female academics aged between 29 and 34, many of whom were employed on short term contracts, felt less able to control the type of research and work they performed than older female academics in the late 40 to 50 age group. Some spoke of having to work on bids for government funded projects they regarded as "unscholarly" (Skelton, 2004: 93).

There is a danger that research is becoming policy-led, and that research identities are becoming colonised as a result of the new research economy (Marginson, 2000). Professional expertise as defined by intellectual rigour is reconstructed to include policy relevance and evidence of "what works". Universities are involved in an increasingly complex set of relations through establishing partnerships with business and venture capitalists, sustaining relations with sponsors and policy-makers, and maintaining the intellectual and scholarly ethos, which has defined the university and sets it apart from other institutions. Universities, however, are differently positioned in relation to the benefits which can be accrued from a marketised higher education system. In his analysis of New Labour's education policies, John Beck (1999) points to the promotion of individualistic and institutional competitiveness as one of the most insidious effects of neo-liberal modes of governance. The shift towards market-based definitions of academic work is also problematic in its blurring of the distinction between public and commercial interests as well as professional and institutional identities (Giroux, 2003; Giroux and Myrsiades, 2001).

\section{$-5-$}

The dominance of the economic imperative can be seen very clearly when regarding the internationalisation of higher education agenda (Harris, 2007). Since the 1990s internationalisation has been an important theme in higher education policy, although the term is used in a variety of ways. For some commentators internationalisation refers to external processes such as globalisation and the emergence of a competitive marketplace, while for others internationalisation is about the internal policies and activities of institutions such as developing an intercultural or global dimension to the curriculum. Internationalisation is also used in relation to international collaboration and 
partnership and knowledge transfer activities (Knight, 2004). For example, the UK government is committed to international education, as evidenced by the Prime Minister's Initiative (PMI) first launched in 1999 as a means of increasing international recruitment. PMI2 builds on the first phase of PMI and aims to secure the position of the UK as a leader in international education. It intends to improve the "UK brand" abroad to achieve market diversification and consolidation, and to develop strong strategic partnerships and alliances. The need to ensure the quality of the student experience is also a part of this strategy.

The term international is also used as an indicator of excellence, with performativity as the main criterion. However, performativity is informed by an impoverished concept of meaning and operates within a restrictive view of education. The manner in which education is understood and practised is limited, and confined to that which can be given expression, quantified, measured, and standardized. The problem with internationalisation driven by an economic imperative is that it implies recognition of difference, but simultaneously gets incorporated into the system and becomes an integral part of its project. A regime of performativity demands standardization, uniformity and commensurability; under such a regime, diversity expressed through different and diverse educational traditions is not acknowledged. This raises important issues concerning developments in European higher education. It is to these I turn next.

\section{$-6-$}

A central concern of the European Union and the European Commission is the need for Europe to respond appropriately to the perceived challenges and threats of a knowledge society, especially in relation to the economic power of the USA, China and India in the global market place. Higher education is seen primarily as performing a crucial economic function; knowledge is considered to be important in giving citizens necessary competences to face the challenges of a globalised economy. The Bologna process, with its goal of a single European Area of Higher Education as a means of increasing the international competitiveness of the European higher education system, can be seen in this light.

In 2000 the European Council agreed in Lisbon that the 2010 strategic target for Europe would be "to become the most competitive and dynamic knowledge-based economy in the world, capable of sustained economic growth with more and better jobs and greater social cohesion" (CEC, 2005). The emphasis on graduate skills and mobility, and the need to hold comparable competences, has led to a great deal of attention being paid to developing more transparent, comparable and standardised education and training across the Member States (OECD, 2004). The central aim of the International Association of Universities (IAU) is also in keeping with EU policy: the IAU wants to increase student and staff mobility, and improve the performance of 
European universities as part of a trend towards both internationalisation and Europeanisation. At the same time, however, universities have become part of a global market and in are competing with each other; their position in the world ranking tables as well as national league tables is increasingly important for attracting investment and students (or both). Such competition is perhaps at its greatest in the UK, while in other countries such as Spain there exists less competition between universities. ${ }^{3}$

As suggested above, Bologna needs to be seen in the broader context of a European policy and a European project that are informed by neo-liberal thinking. The cultural dimension that was present in the 1999 Bologna Declaration has been overtaken by an economic imperative prompted by the European Union and European Commission. The Bologna Agreement was a university rather than an EU initiative: prior to the 1999 Bologna Declaration, university rectors who had gathered in Bologna to celebrate the $900^{\text {th }}$ anniversary of the University of Bologna had signed the Magna Charta of European Universities. This document included the following statement:

The university is an autonomous institution at the heart of societies ... To meet the needs of the world around it, its research and teaching must be morally and intellectually independent of all political authority and economic power.

Ten years later, in Sorbonne, Ministers of higher education in the UK, France, Germany and Italy signed a "Joint Declaration on the harmonization of the architecture of the European higher education system" (Bologna Declaration, 1999). A central aim of this was to increase student mobility as a means of fostering a common European cultural identity. A year later the Bologna Declaration was signed, a central aim of which was to world-wide promote a European system of higher education. Its objectives included the adoption of a system of easily readable and comparable degrees, the establishment of a system of credits, the promotion of mobility by students, teachers and researchers and European cooperation in quality assurance, and the development of a European dimension to higher education.

Voldemar Tomusk (2004) suggests that Bologna was "highjacked" and misused by the European Commission to pursue its own agenda of emphasising the economic and political over the cultural with the goal of making

3. The economic imperative is also reflected in university mission statements where primary concern is attached to economic objectives. In the United States in the 1990s, colleges and universities introduced logos and mascots designed to attract a market of potential students. Bill Readings (1996) describes the American university as a corporation primarily concerned with its position in the market; the cultural transmission gained through a degree and qualification is secondary to the economic gain for the institution. 
Europe a strong player in the knowledge economy. This view finds support in Jan Masschelein and Maarten Simons' (2002) analysis, in which they argue that the European Area of Higher Education is effectively the creation of a market environment where schools, teachers and pupils behave in an entrepreneurial manner. In her work on the role of the European Union in shaping education policy, Jacky Brine (2008) examines the way in which the presence and influence of the EU continues to grow, using Bologna to extend its role and to promote the economic imperative. At the Berlin summit in 2003, for example, the European Commission was confirmed as a full member of the Bologna Process and the Bologna Board (Brine, 2008).

A similar analysis can be made of the European Research Area. Maarten Simons (2006) considers how education through research is seen as crucial to a European knowledge society. He argues persuasively that by using the word "through" in the phrase "education through research" the European Commission is conjuring up an idea that was central to the Humboldtian ideal of the university: the university as a research institution where education, through participation in research, would lead to Bildung or edification. However, the way in which the Commission uses the phrase is far removed from the original. ${ }^{4}$ For Wilhelm von Humboldt research in the university takes place not for the sake of the student; instead, both research and the student serve the pursuit of truth. In the European perspective, by contrast, research is seen as a teaching method. The competences that the European Commission identifies are considered similar to those found in research, but the competences it emphasises are primarily about being entrepreneurial or economically competent, and little else. This bears little resemblance to Humboldt's idea of education through research, guided by an idea that transcends society. In the knowledge society the university is not regarded as an institution "that offers orientation for society; rather the opposite seems to be the case: it is society and its needs that should orient the university" (Simons, 2006: 34). Equally, the point of departure is not the edifying potential of academic enquiry and research, but the educational needs of the knowledge society.

\section{$-8-$}

The European project has as its goal a united and unitary "New Europe", underpinned by a particular conception of human beings as self-interested consumers. European education policy is part of a wider neo-liberal project in which education is constructed in rationalist and instrumentalist terms; its role is to create economic agents who will contribute to the development of an entrepreneurial society. The language is that of a competitive individualism where education is seen as a service industry for the social market. The cultural

4. The role of the universities in knowledge production received very little attention when the idea of a European Research Area was first conceived. 
transmission acquired through a degree and a qualification is now secondary to the economic gain for the institution (Readings, 1996).

In a performative society everything has to be measured using the same criteria and standards; everything has to be commensurable and difference is obscured. A "technicist" and instrumentalist language pervades the political debate as well as education policy and practice. Debate is centred on a concern to find out what leads to more efficient and effective practices. "What works?" is the only question considered worth asking. Intellectual and moral questions about the aims of education, by contrast, are not deemed legitimate as the ends and the values are already given, namely to be effective and efficient. The nature of education is constrained and confined to that which can be given expression and can be measured and standardised. The intrinsic value of education is not recognised either. There is no space and no recognition of the purpose of education as a means for questioning the self and society; that question can no longer be asked. As Pádraig Hogan (1998: 363) has noted, the European Commission's 1996 White Paper, Teaching and Learning: Towards the Learning Society, stated that all debates about the aims of education were over and the "distinction between education and training is obsolete."

There is no space to think about difference and what this means in a globalised economy. The diversity of national education systems, which historically has been seen as a strength, is now considered problematic because the drive for performativity and commensurability that underpins EU education policy ignores or denies the actual practice that is involved: everything is treated the same and subject to the same criteria of evaluation (Harris, 2007). The emphasis shifts from substance to procedure, and the danger is that differences are played down or neutralised in the pursuit of standardisation and uniformity. A shift has occurred from a concern about substantive knowledge to an emphasis on skills and acquiring the appropriate competences, of learning to learn and accessing information. This is the discourse of lifelong learning and the learning society. (Ranson, 2003; Masschelein and Simons, 2002).

\section{$-9-$}

One of the objectives of the Bologna Declaration was to encourage student mobility to experience study in different institutions of higher education within the European Union. This is a worthy goal, but it is unclear how greater intercultural understanding or new ways of thinking is possible under the kind of European higher education currently promoted by the EU. A different kind of spirit for Bologna is needed, one which does not have as its educational goal the promotion of economic agents but rather an openness to a greater understanding of our relationship with others. This would constitute an intercultural engagement and cultural dimension that is alluded to, but not realised, in current European higher education policy. The internationalisation of higher education offers a space for asking complex questions, but it requires a different kind of language to that which is prevalent in current policy 
discourse. More attention needs to be paid to language and to new ways of thinking about education; we need a more subtle language that moves beyond the impoverished language of policy discourse and performativity.

\section{References}

Altbach, P. G. and Peterson, P. M. (1999). Higher Education in the 21st Century: Global Challenge and National Response. New York: Institute of International Education; Boston College Center for International Higher Education.

BECK, J. (1999). "Makeover or Takeover? The Strange Death of Educational Autonomy in England". British Journal of Sociology of Education, 20 (2), 223-238.

Bernstein, B. (2000). Pedagogy, Symbolic Control and Identity: Theory, Research and Critique (revised ed.). Lanham, NJ: Rowman \& Littlefield.

Bourdieu, P. (1988). Homo Academicus. Cambridge: Polity Press.

BOLOGNA DECLARATION (1999). The European Higher Education Area. Joint declaration of the European Ministers of Education convened in Bologna, 19 June 1999. Available from: http://ec.europa.eu/education/policies/educ/bologna/ bologna.pdf (Accessed 11 October 2010).

BRIDGES, D. (2006). "The practice of higher education: in pursuit of excellence and equity" in Educational Theory 56 (4), 371- 386.

BRINE, J. (2008), 'The boundaries of competency within Lisbon and Bologna: the short-cycle/foundation learner', European Education Research Journal, 7 (3), 344-357.

Brooks, A. (2001). "Restructuring Bodies of Knowledge". In: Brooks, A. and MACKINNON, A. (Eds.), Gender and the Restructured University. Buckingham: The Society for Research into Higher Education \& Open University Press.

CEC (2005). Mobilizing the Brainpower of Europe: Enabling Universities to Make Their Full Contribution to the Lisbon Strategy. Brussels: European Commission.

Cunningham, S.; Ryan, Y.; Steadman, L.; Tapsall, S.; Bagdon, K.; Flew, T. and Coaldrake, P. (2000). The Business of Borderless Education. Canberra: Department of Education, Training and Youth Affairs Evaluation and Investigations Program (EIP), Higher Education Division.

HARRIS, S. (2007). The Governance of Education: How Neo-liberalism Is Transforming Policy and Practice. London: Continuum.

- (2008). "Internationalising the University". Educational Philosophy and Theory, 40 (2), 346-357.

- (2011). The University in Translation: internationalizing higher education. London: Continuum International Press.

Hogan, P. (1998). "Europe and the World of Learning: Orthodoxy and Aspiration in the Wake of Modernity". Journal of Philosophy of Education, 32 (3), 361-376.

IRDAC (Industrial Research and Development Advisory Committee) (1994). Quality and Relevance: The Challenge to European Education. Brussels: IRDAC.

Giroux, H. (2003). "Selling Out Higher Education". Policy Futures in Education, 1 (1) $179-200$.

Giroux, H. and Myrsiades, K. (Eds.) (2001). Beyond the Corporate University. Oxford: Rowman \& Littlefield Publishers.

KNIGHT, J. (2004). "Internationalization Remodelled: Definition, Approaches, and Rationales". Journal of Studies in International Education, 8 (1), 5-31. 
LujTen-Lub, A. (2007). Choices in Internationalisation: How Higher Education Institutions Respond to Internationalisation, Europeanisation, and Globalisation. Enschende: Centre for Higher Education Policy Series, University of Twente.

LyOTARD, J.F. (1984). The Postmodern Condition: A Report on Knowledge. Manchester, Manchester University Press.

Marginson, S. (1995). "Markets in Higher Education: Australia”. In: SMYTH, J. (Ed.), Academic Work. Buckingham: The Society for Research into Higher Education \& Open University Press, 17-39.

- (2000). "Research as a Managed Economy: The Costs", in CoAdy, T. (Ed.), Why Universities Matter. A Conversation about Values, Means and Directions. Sydney: Allen and Unwin

Masschelein, J. and Simons, M. (2002). “An Adequate Education in a Globalised World? A Note on Immunisation Against Being-Together”. Journal of Philosophy of Education, 36 (4), 589-608.

OECD (2004). Internationalisation of Higher Education. Paris: OECD.

Peters, M. and Humes, W. (2003). "Education in the Knowledge Economy". Policy Futures in Education, 1 (1), 1-19.

Ranson, S. (2003). Public Accountability in the Age of Neo-liberal Governance". Journal of Education Policy, 18 (5), 459-480.

READIngs, B. (1996). The University in Ruins. Cambridge, MA.: Harvard University Press.

ScotT, P. (Ed.) (1998). The Globalization of Higher Education. Buckingham: The Society for Research into Higher Education \& Open University Press.

- (2000). "Globalisation and Higher Education: Challenges for the Twenty-first Century". Journal of Studies in International Education, 4 (1), 3-10.

Simons, M. (2006). "Education Through Research' at European Universities: Notes on the Orientation of Academic Research". Journal of Philosophy of Education, 40 (1), 31-50.

Skelton, C. (2004). "Gender, Career and 'Individualisation' in the Audit University”. Research in Education, 72, 87-101.

Slaughter, S. and Rhodes, G. (2004). Academic Capitalism and the New Economy: Markets, State and Higher Education. John Hopkins University Press.

Tomusk, V. (2004). “Three Bolognas and a Pizza Pie: Notes on Institutionalization of the European Higher Education System". International Studies in Sociology of Education, 14 (1), 75-96.

Watson, D. (2007). Managing Civic and Community Engagement. Berkshire, Open University Press. 